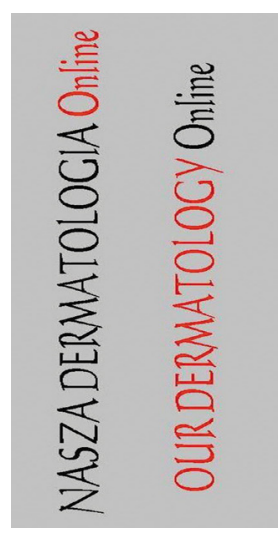

\title{
ATOPIC DERMATITIS AND HOMEOPATHY
} ATOPOWE ZAPALENIE SKORY A HOMEOPATIA

\section{Lawrence Chukwudi Nwabudike}

\author{
N. Paulescu Institute of Diabetes, Bucharest Str. I.L. Caragiale, nr. 12, sector 2, \\ Bucharest, Romania
}

Corresponding author: Dr. Lawrence Nwabudike Chukwudi.nwabudike@live.com

\begin{tabular}{rr}
\hline Our Dermatol Online. 2012; 3(3): 217-220 & $\begin{array}{r}\text { Date of submission: } 16.03 .2012 / \text { acceptance: } 17.04 .2012 \\
\text { Conflicts of interest: None }\end{array}$ \\
\hline
\end{tabular}

\begin{abstract}
Introduction: Atopic dermatitis (AD) is a chronic, relapsing disorder of the skin associated with allergen sensitization and impaired barrier function. There is often a family history of pruritic skin disease or asthma. Materials and Methods: Three cases of atopic dermatitis treated with homeopathy are presented. Case 1 is a case of a 22 -year-old female, with AD since early childhood, which had not responded to standard topical therapy. She received several homeopathic medicines, with transitory effect until she finally received the medicine Aurum metallicum, at $\mathrm{M}$ potency. At present, 1 year after cessation of treatment, she remains lesion-free. Case 2 is a case of a 10-month-old baby with a an 8 -month history of itchy rash and poor sleep, that had failed to respond to treatment. The patient was given the homeopathic medicine Lachesis at $\mathrm{C} 30$ potency and responded. The rashes receded and the patient was able to sleep better at night. Case 3 is a case of an 11-month-old boy with a 3-month history of itchy rash, diagnosed as having AD and treated with topical steroids. After 3 months of unsuccessful treatment, the patient was brought in for homeopathic therapy. He received the homeopathic medicine Lachesis, at C30 potency. He improved under this treatment and is currently lesion-free, 6 months after cessation of treatment. Conclusions: Three cases of atopic dermatitis that failed to respond to treatment were given homeopathic therapy and responded adequately. The patients remained free of lesions even after cessation of treatment.
\end{abstract}

\section{Streszczenie}

Wprowadzenie: Atopowe zapalenie skóry (AZS) jest przewlekłą, nawracającą chorobą skóry związaną z alergią i upośledzeniem funkcji barierowej. W wywiadzie rodzinnym stwierdzić można świąd skóry lub astmę. Materiał i metody: Prezentowane są trzy przypadki atopowego zapalenia skóry leczonego homeopatią. Przypadek 1 jest przypadkiem 22-letniej kobiety z AZS od wczesnego dzieciństwa, które nie odpowiedziały na standardowe leczenie miejscowe. Otrzymała kilka leków homeopatycznych, z krótkotrwałym efektem, do czasu kiedy przyjęła lek Aurum metallicum w potencji M. Obecnie 1 rok po zakończeniu leczenia, pozostaje bez zmian chorobowych. Przypadek 2 to 10-miesięczne dziecko z 8-miesięczną historią swędzącej wysypki skórnej i zaburzeniami snu, nie odpowiadała na leczenie. Pacjentka otrzymała lek homeopatyczny Lachesis w potencji C30 i pozytywnie zareagowała. Zmiany skórne ustąpiły, a pacjentka mogła lepiej spać w nocy. Przypadek 3 to 11-miesięczny chłopiec z 3-miesięczną historią swędzących zmian skórnych, u którego zdiagnozowano AZS i traktowano miejscowymi kortykosteroidami. Po 3 miesiącach nieudanego leczenia, pacjent został poddany homeopatii. Otrzymał homeopatyczny lek Lachesis, w potencji C30. Chłopiec poprawił się w ramach tej terapii i jest obecnie wolny od zmian skórnych, jest 6 miesięcy po zakończeniu leczenia. Wnioski: Trzy przypadki AZS, nie odpowiadające na leczenie poddano homeopatii z dobrą odpowiedzią końcową. Pacjenci pozostali bez zmian skórnych nawet po zaprzestaniu leczenia.

Key words: atopic dermatitis; eczema; homeopathy; pruritus; lachesis;Aurum metallicum

Slowa klucze: atopowe zapalenie skóry; wyprysk; homeopatia; świąd; lachesis; Aurum metallicum

\section{Introduction}

Atopic dermatitis (AD) is a chronic, relapsing disorder of the skin associated with allergen sensitization and impaired barrier function. There is often a family history of pruritic skin disease or asthma [1]. It appears to be commoner in urban than in rural areas and in the industrialised as opposed to less industrialised countries. In India, the prevalence was $2.4-6 \%$ of 37000 children [2], and $8.5 \%$ of 1019 south-eastern Nigerian patients had $\mathrm{AD}$ [3]. Others suggest an incidence of
AD of $15-20 \%$ of children in industrialised nations [1]. The exact cause or causes of AD are unknown. However, breastfeeding for at least 3 months appears to reduce the risk in infants of atopic dermatitis [4]. Genetic factors may play a role, as there is a higher rate $(77 \%)$ amongst monozygotic twins than in dizygotic twins (15\%) [5]. Several loci on genes have been linked to atopic dermatitis [5]. There is also an increased concentration of inflammatory cytokines, including interleukins, in atopic skin [6]. 


\section{Material and Methods}

Three patients with atopic dermatitis that had failed to respond to previous treatments were treated homeopathically by this author. Their characteristics and response to treatment are presented.

\section{Patient 1}

A 22-year old economics student presented with an erythematous rash on her upper lip, associated with itching (Fig. 1-4). Her past medical history at this visit was not significant, but a later visit revealed a history of itchy rash since early childhood and migraine headaches. After several visits, in which she received homeopathic treatments, the symptoms appeared to worsen with increased rashes, which only showed transitory improvement. Finally, she received the homeopathic medicine Aurum metallicum at $\mathrm{M}$ potency. The rash disappeared and, 1 year after this treatment, she only has residual mild dry skin around the neck area. The migraines have diminished greatly in intensity and frequency also.

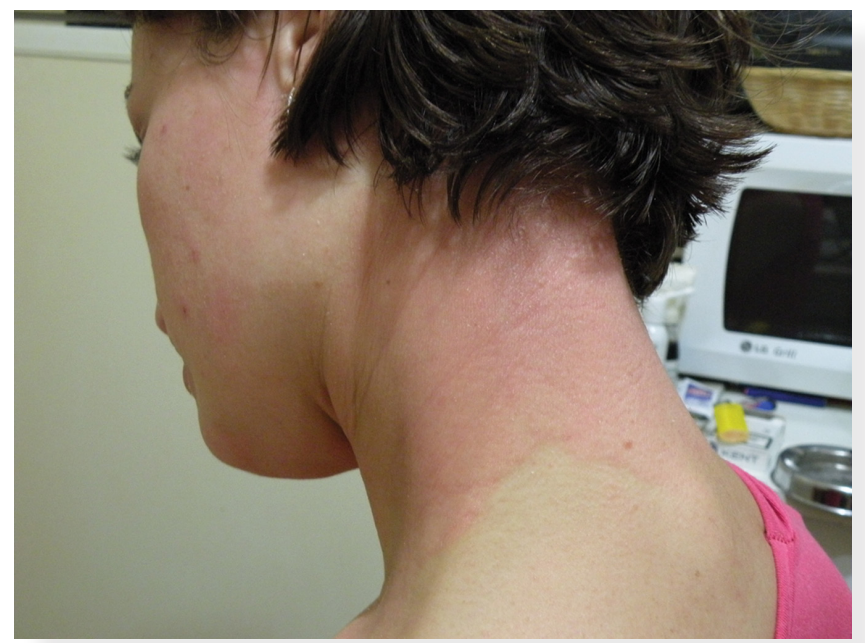

Figure 1. 22-year old woman - atopic dermatitis on the neck - before treatment

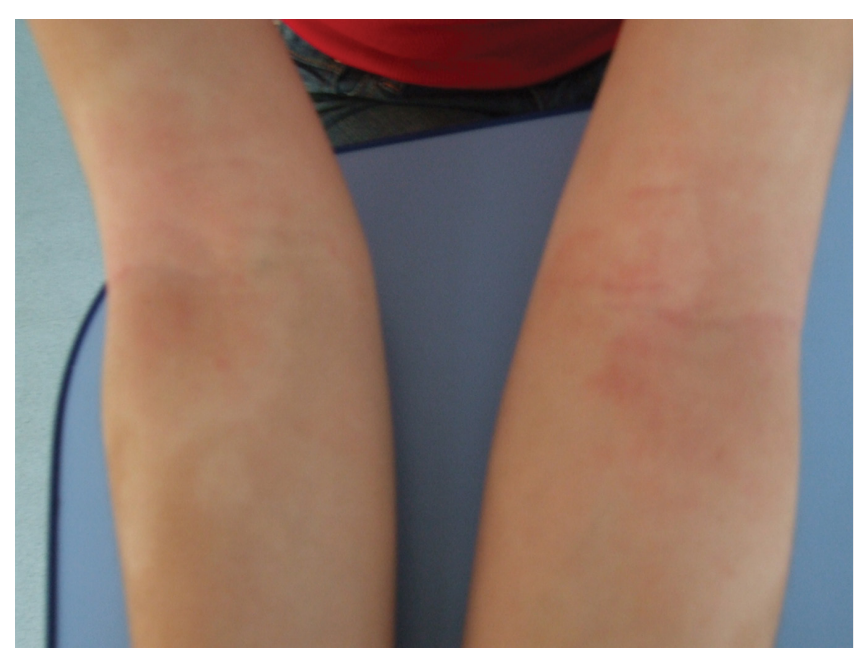

Figure 2. 22-year old woman - atopic dermatitis on the hands - before treatment

\section{Patient 2}

A 10-month old baby girl presented with a generalized, itchy rash (Fig. 5-7).

The itch was aggravated by heat and by bathing (the mother had read somewhere that bathing with very warm water

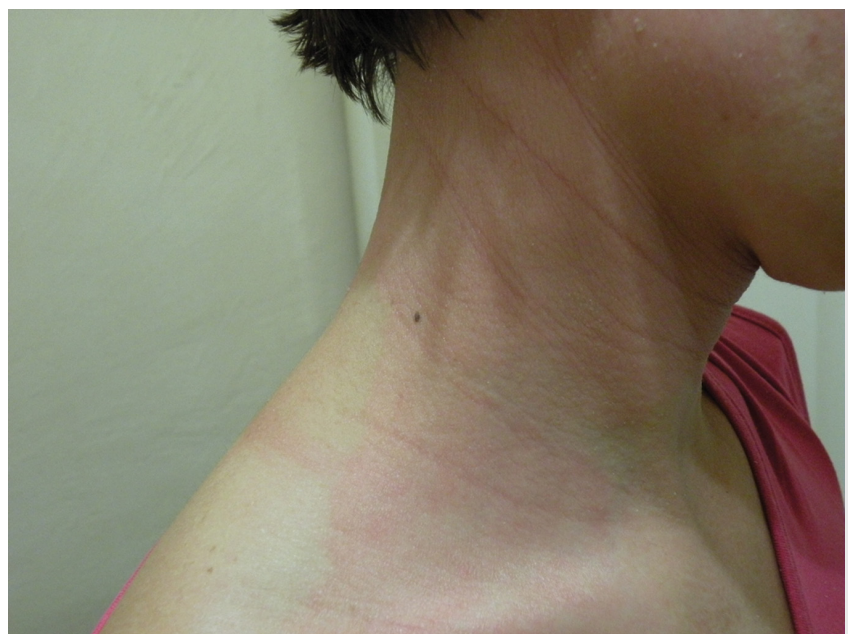

Figure 3. 22-year old woman - atopic dermatitis on the neck - before treatment

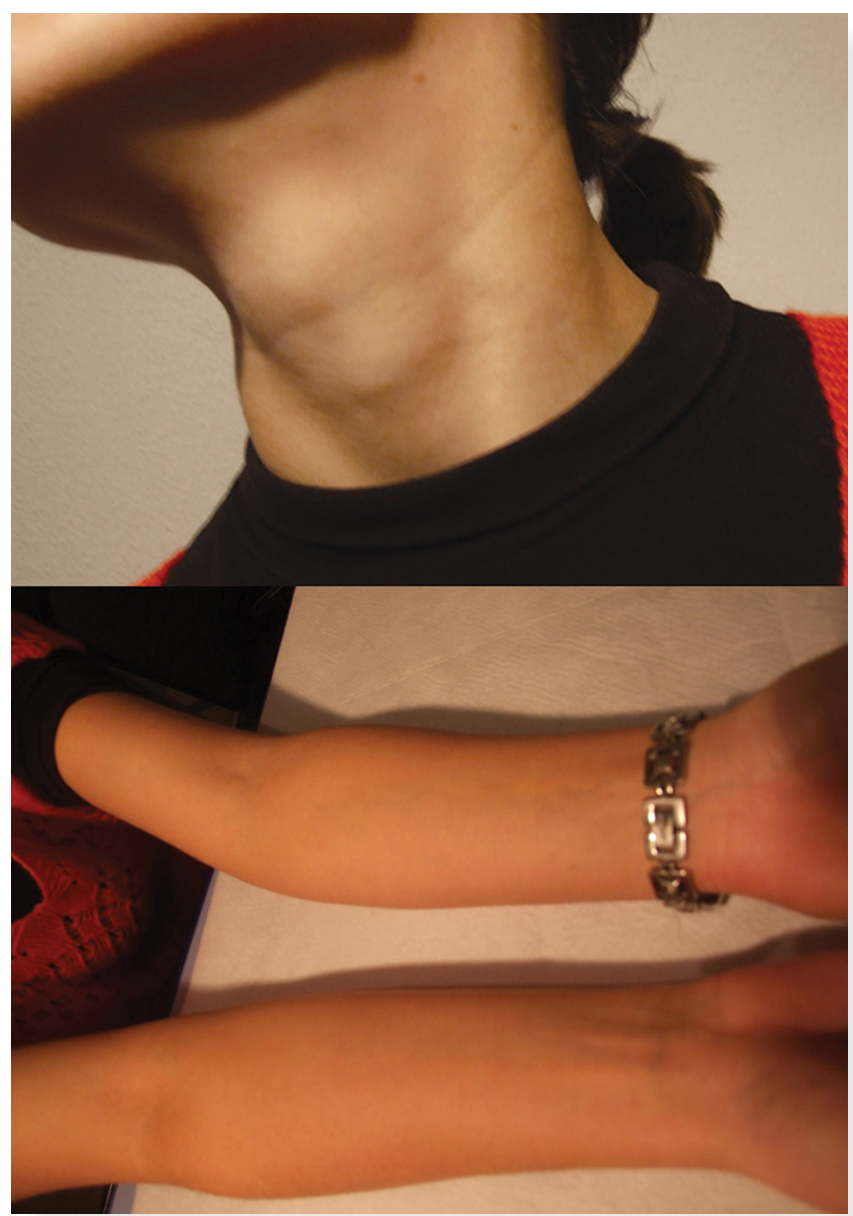

Figure 4. 22-year old woman - skin lesions after treatment

was healthy). The patient frequently woke at night and had restless sleep.

Past medical history revealed a history of dry skin in the mother and parapsoriasis in the maternal grandfather. All developmental milestones were met and vaccinations had been given on schedule.

On examination, the child had erythematous, squamous patches, with some weeping lesions that also affected the flexural and extensor areas of the limbs, the face and neck. She received the homeopathic medicine Lachesis at C30 potency. The patient continued to improve under this treatment and, 6 months after cessation of treatment, continues to remain almost completely lesion- and symptomfree. The patient has also resumed normal sleep patterns. 


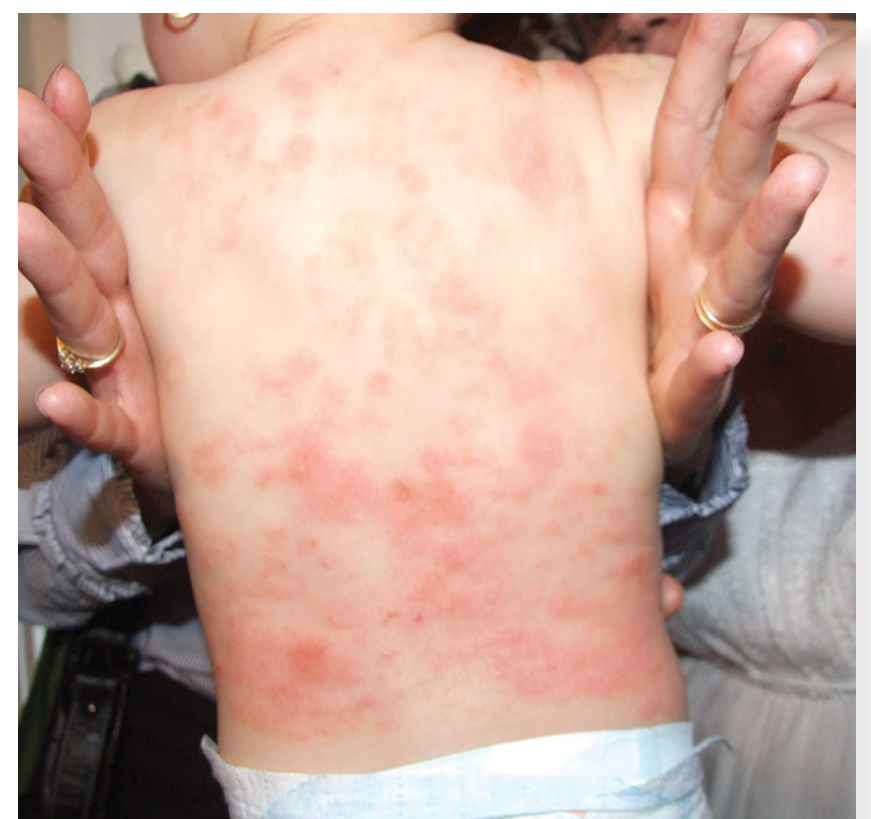

Figure 5. 10-month old baby girl - atopic dermatitis on the back - before treatment

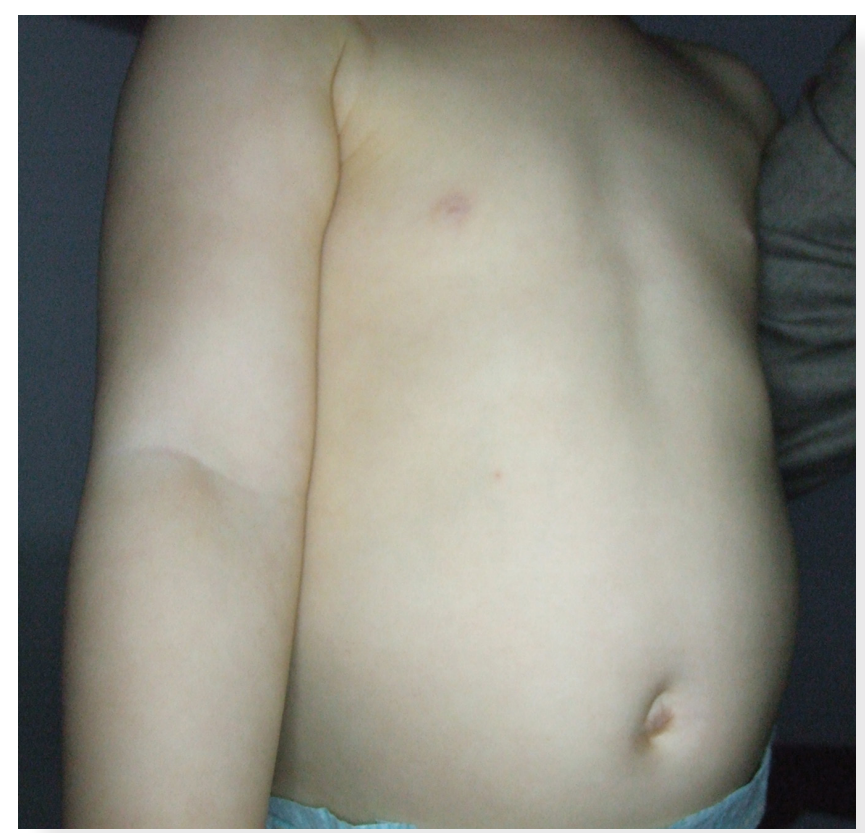

Figure 7. 10-month old baby girl - 6 months after cessation of treatment

\section{Patient 3}

An 11-month old baby boy presented with a 3 month history of generalized itchy rash (Fig. 8,9).

There was no family history suggestive of atopy. All developmental milestones were normal and vaccinations were up to date.

On examination there were generalized, erythematous, squamous plaques, concentrated in the upper chest, neck and abdominal areas. There was relative facial sparing.

The patient received the homeopathic medicine Lachesis at C30 potency and showed improvement. He was lesion-free by one month and, 3 months later, remains free of lesions.

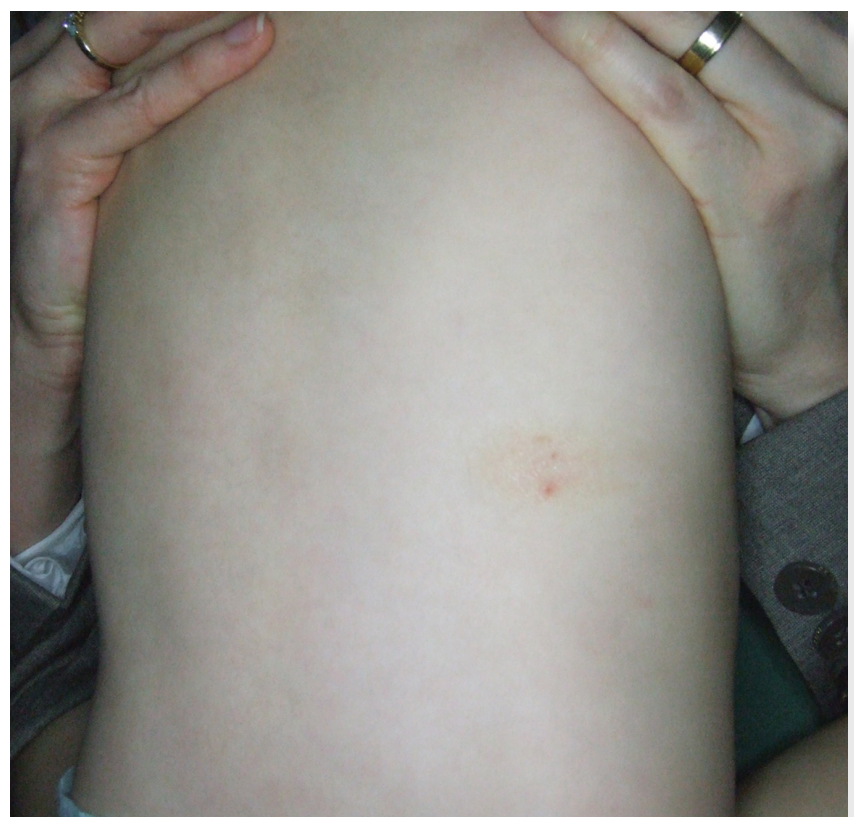

Figure 6. 10-month old baby girl - just after treatment

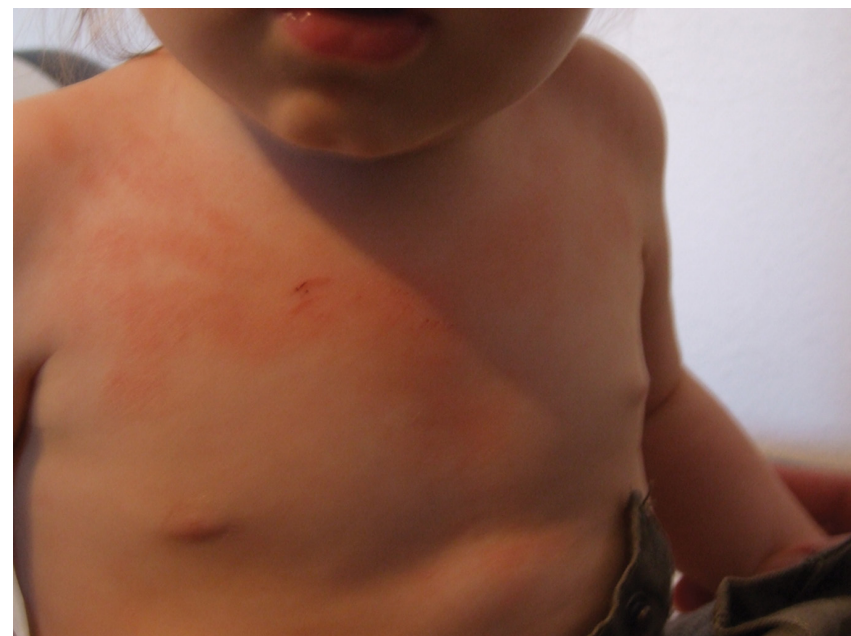

Figure 8. 11-month old baby boy - atopic dermatitis on the thorax - before treatment

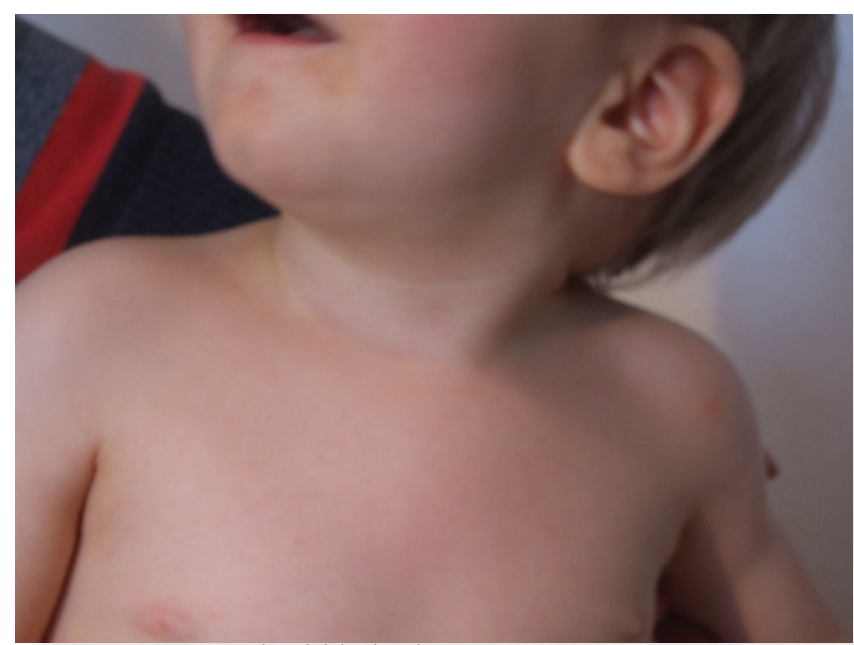

Figure 9. 11-month old baby boy - after treatment 


\section{Discussion}

$\mathrm{AD}$ is a fairly common skin condition. It is commoner in industrialised nations, though its prevalence in non-industrialised countries is on the rise. Pruritus and cutaneous irritability are the most important features of atopic dermatitis. Criteria for diagnosis are major and minor. The major criteria include pruritus, rash with typical morphology and personal or family history of atopic disease. Minor criteria include xerosis (dry skin), elevated serum IgE, itchy rash in skin creases. Nipple eczema, cheilitis, Dennie-Morgan infraorbital fold and itch while sweating, amongst others [7]. Various treatment strategies are used for $\mathrm{AD}$, including emmolients, topical and systemic steroids, calcineurin inhibitors, UVB therapy and probiotics [1,7,8]. In this paper, three cases of $\mathrm{AD}$ have been presented. They responded positively to homeopathic therapy and continued to remain well after the cessation of treatment. This author has found homeopathy to be useful for various disorders including common warts, seborrheic dermatitis, psoriasis, rosacea and melasma [8-12]. Putative mechanisms have been put forward for the mechanism of action of homeopathy $[13,14]$. A good review of the principles of homeopathy has recently been published and the case for the use of homeopathy by virtue of its effectiveness was made [15]. Efficacy was defined as the production of a therapeutic effect in clinical trials, while effectiveness the ability to produce an effect in clinical practice [15]. Homeopathy appears to have been clearly effective in $\mathrm{AD}$, in the cases presented.

\section{Conclusions}

$\mathrm{AD}$ is a cutaneous, inflammatory skin disorder that is common amongst children and is on the increase in both industrialised and non-industrialised nations. Various therapeutic methods exist for the treatment of this disorder. Homeopathy is a cheap, mild form of treatment with almost no known adverse effects, which has been found useful in a number of cutaneous disorders. We present 3 cases of $\mathrm{AD}$ that responded to homeopathic treatment and remained in remission after cessation of treatment. Homeopathy may be a useful new treatment modality for AD and further studies and clinical trials are required to establish whether it may be efficacious in the therapy of this disorder.

\section{REFERENCES}

1. Leung DYM, Eichenfield LF, Boguniwicz M: Atopic Dermatitis (Atopic Eczema) [in] Fitzpatrick's Dermatology in General Medicine. Wolff K, Goldsmith LA, Katz SI, Gilchrest BA, Paller AS, Leffel DJ, McGraw Hill Publishers, 2008.

2. Kanwar AJ, De D: Epidemiology and Clinical Features of Atopic Dermatitis in India. Indian J Dermatol. 2011; 56: 471475.

3. Nnoruka EN: Current Epidemiology of Atopic Dermatitis in South-Eastern Nigeria. Int. J. Dermatol. 2004; 43:739-744.

4. Kramer MS: Breastfeeding and Allergy: the evidence. Ann Nutr Metab. 2011; 59(Suppl 1): 20-26.

5. Bieber T: Atopic Dermatitis. N Engl J Med 2008; 358: 14831494.

6. Nobbe S, Dziunycz P, Mühleisen B, Bilsborough B, Dillion SR, French LE, et al: IL-31 Expression by Inflammatory Cells is Preferentially Expressed in Atopic Dermatitis. Acta Derm Venereol. 2012; 92: 24-28.

7. James WD, Berger T, Elston DM: Atopic Dermatitis, Eczema and Noninfections Immunodeficiency Disorders [in] Andrews' Diseases of the Skin. Clinical Dermatology. 10th ed., SaundersElsevier Publishers, 2006.

8. Nwabudike LC: Homeopathy in the treatment of verrucca vulgaris - an experience of two cases. Proc. Rom. Acad. 2010; 2: $147-149$.

9. Nwabudike LC: Seborrheic Dermatitis and Homeopathy. Our Dermatol Online 2011; 2: 208-210.

10. Nwabudike LC: Psoriasis and Homeopathy. Proc. Rom. Acad. 2011; 3: 237-242.

11. Nwabudike LC: Rosacea and Homeopathy. Proc. Rom. Acad. In Press

12. Nwabudike LC: Homeopathy and Melasma - A Case Presentation. Homeopathic Links (Verlag Thieme, Germany). In Press

13. Montagnier L, Aïssa J, Ferris S, Montagnier J-L, Lavalléee C: Electromagnetic signals are produced by aqueous nanostructures derived from bacterial DNA sequences. Interdiscip Sci Comput Life Sci. 2009; 1: 81-90.

14. Chicramane SP, Sukresh AK, Bellare RJ, Kane GS: Extreme homeopathic materials retain starting materials: a nanoparticulate perspective. Homeopathy. 2010; 99: 231-242.

15. Erlewyn-Lajeunesse M: Homeopathic Medicines for Children. Arch Dis Children. 2012; 97: 135-138.

Copyright by Lawrence Chukwudi Nwabudike. This is an open access article distributed under the terms of the Creative Commons Attribution License, which permits unrestricted use, distribution, and reproduction in any medium, provided the original author and source are credited. 